\title{
How Have the CLV Economies been Exposed to Financial Vulnerabilities?
}

\author{
Vo Tri Thanh, Serey Chea, Sarat Ouk and Le Xuan Sang*
}

\begin{abstract}
1 Introduction
Cambodia, Laos and Vietnam (CLV) have embarked on market-oriented reforms since the mid-1980s. While sharing several similarities, the reforms and international integration processes of CLV have differed significantly, in terms of both pace and extent.
\end{abstract}

Despite being initiated in 1986, the market-oriented reform measures in Cambodia have been accelerated, with wider scope, only since 1989. At the end of 1993, the reforms were notably strengthened, especially with a programme for rehabilitation and reconstruction introduced by the newly elected government. Since 2001, Cambodia has made considerable progress in some key structural reform areas; however, the implementation of some other important structural reforms has been delayed and uneven. After the accession to World Trade Organization (WTO) in 2003, despite some delays, its government has made significant efforts in legislation work. Cambodia then committed to drastic market-oriented reforms within a transitional period of five years.

Laos officially commenced its economic transformation under the New Economic Mechanism in 1986. Similar to Cambodia, Laos accelerated economic reforms ${ }^{1}$ in 1989, and has made more significant progress towards a market economy since 1992. Nevertheless, the momentum of economic reform in Laos flagged during $1997-8$ when the regional financial crisis erupted. Since mid-1999, in response to the deteriorating macroeconomic environment, the country has undertaken strong stabilisation measures by tightening fiscal and monetary policies. After 2000, Laos had made certain progress in market-oriented reforms, particularly structural reforms in public expenditure management, monitoring and restructuring stateowned enterprises (SOEs), as well as strengthening its financial sector since July 2002. The overall pace, however, has been slow.

Vietnam officially introduced Doimoi (Renovation) in 1986, but only started a radical and comprehensive reform package aiming at stabilising and opening the economy in 1989. However, during 1996-9, reforms were somewhat retarded, particularly after the Asian financial crisis. Since 2000, a new wave of economic reforms has been stirred up with emphasis on structural reforms (SOE and financial reforms), development of the private sector, and further trade and investment liberalisation. The years 2000-6 witnessed a boom of private sector and deeper international economic integration. ${ }^{2}$ Meanwhile, the reforms of SOE sector, banking system, and public administration were slower than expected.

The market-oriented reforms have led to major changes in the CLV economies. Undoubtedly, liberalisation of trade and balance of payments (BOP) has contributed significantly to their economic growth and development during the 1990s and in the early 2000s. Nevertheless, the financial and currency crises in the 1990s, especially the Asian crisis in 1997-8, showed that this process, if implemented improperly, could involve risks.

This article attempts to shed light on possible risks associated with the key macroeconomic fundamentals, current account (CA) balance and capital flows, financial system and foreign exchange policies in CLV. Section 2 discusses the problem of 


\begin{tabular}{|c|c|c|c|c|c|c|}
\hline & 2000 & 2001 & 2002 & 2003 & 2004 & 2005 \\
\hline \multicolumn{7}{|l|}{ Cambodia } \\
\hline Merchandise export growth (\%) & - & 12.5 & 11.7 & 15.5 & 22.1 & 17.6 \\
\hline Merchandise import growth (\%) & - & 7.9 & 10.7 & 10.4 & 24.7 & 23.0 \\
\hline Trade balance as \% GDP & -14.9 & -13.2 & -13.2 & -11.6 & -13.6 & -16.4 \\
\hline Trade openness (total trade/GDP; \%) & 91.4 & 92.3 & 95.2 & 99.9 & 107.6 & 110.4 \\
\hline CA balance (\% GDP) & -3.1 & -1.2 & -1.2 & -3.2 & -3.6 & -5.1 \\
\hline \multicolumn{7}{|l|}{ Laos } \\
\hline Merchandise export growth (\%) & 0.9 & -3.2 & 1.8 & 17.9 & 7.4 & 27.4 \\
\hline Merchandise import growth (\%) & 1.4 & -3.6 & 5.2 & 8.4 & 9.5 & 12.7 \\
\hline Trade balance as \% GDP & -4.9 & -4.8 & -5.4 & -5.8 & -13.8 & -10.9 \\
\hline Trade openness (total trade/GDP; \%) & 52.1 & 49.7 & 50.1 & 48.8 & 68.8 & 71.2 \\
\hline CA balance (\% GDP) & -7.3 & -4.6 & -2.3 & -0.3 & -0.5 & -1.8 \\
\hline \multicolumn{7}{|l|}{ Vietnam } \\
\hline Merchandise export growth (\%) & 25.5 & 3.8 & 11.2 & 20.6 & 31.5 & 23.5 \\
\hline Merchandise import growth (\%) & 33.2 & 3.7 & 21.8 & 27.8 & 26.7 & 18.1 \\
\hline Trade balance as \% GDP & -3.7 & -3.6 & -8.7 & -12.8 & -12.0 & -9.5 \\
\hline Trade openness (total trade/GDP; \%) & 96.6 & 95.6 & 104.0 & 114.7 & 128.6 & 133.4 \\
\hline CA balance (\% GDP) & 2.1 & 2.1 & -1.7 & -4.7 & -2.0 & 0.3 \\
\hline
\end{tabular}

Notes IMF (2005) for figures of Laos; data of 2003 are estimated; ADB (2005) for Laotian figures in 2004, figures for 2005 are projected.

Source Cambodian Ministry of Economy and Finance (2006), ICSEAD (2006), IMF (2005) and ADB (2005) and authors' estimation.

getting fundamentals right in the three economies. Not only growth and export performance and CA balance, but their sustainability and dynamism are also under consideration. Section 3 examines both the adequacy of capital flows as sources of financing CA deficits as well as the external debt burden CLV are facing. Section 4 then provides a primary analysis of how vulnerable CLVs' financial system is, especially in regards to the banking sector. Section 5 discusses the appropriateness of exchange rate regimes and the levels of international reserves in CLV. Section 6 concludes by giving some policy recommendations for CLV to sustain economic growth, while mitigating the possible financial risks.

\section{Getting the fundamentals right?}

Since the Asian crisis, CLV have experienced quite rapid economic growth, despite adverse shocks including the global and regional economic slowdown in 2001, the outbreaks of the severe acute respiratory syndrome (SARS) in 2003 and the ongoing threat from avian influenza since 2004, and particularly the persistent high rise in oil prices in recent years. Higher economic growth in Cambodia and Vietnam has been associated with lower consumer price index (CPI) inflation (Figure 1). The CLV exports have expanded relatively fast and they are now very open in terms of trade to GDP, especially in the cases of Cambodia and Vietnam. Notably, all three economies have experienced huge trade deficits but relatively low CA deficits (Table 1).

The Cambodian economy has performed quite impressively. GDP growth in the last five years averaged at around 9 per cent per annum, and even reached double-digit levels in 1999, 2004 and 2005 


\section{Figure 1 GDP growth vs. inflation in CLV, 1998-2006}

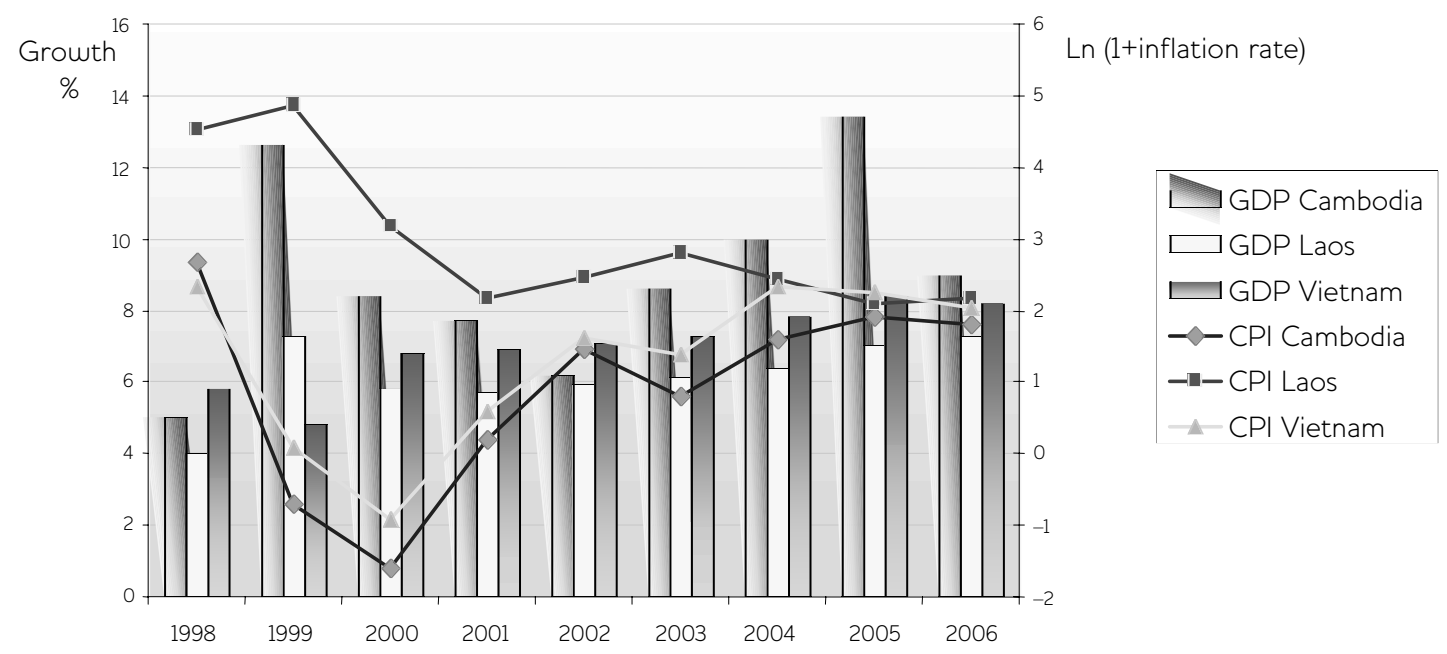

Notes Figures for 2006 (of Laos) are IMF estimates; figures of Cambodia and Vietnam for 2006 are respective estimates by Cambodian Ministry of Planning and Vietnam's General Statistics Office. Source World Economic and Financial Survey (2002, 2006), Cambodian Ministry of Planning (2006b) and Vietnam's GSO.

(Figure 1). In 2006, its estimated growth rate declined, but remained strong at about 9 per cent. Such dynamism of the Cambodian economy has resulted primarily from rapid growth of the industry and services sector, both at 12.1 per cent in 2005. Manufacturing was the best performer in terms of growth rate and sustainability during 1995-2005. Notably, the garment sub-sector plays an important role in the manufacturing and export performance of the country. Tourism has largely dominated the service sector. After being severely hit in 1997 and 1998, the tourism sector has recovered quickly since 1999, as restored consumer confidence fuelled an expansion of domestic and foreign demand for services.

Cambodia's exports and imports have experienced high growth rates in recent years. During 2001-5, annual export growth was at two-digit level, and was noticeably faster after WTO accession in 2003. A similar trend can be seen in the country's imports. Consequently, Cambodia has become one of the most open nations in terms of trade to GDP (110.4 per cent in 2005). However, higher growth and bigger volume of imports have resulted in a huge trade deficit (Table 1).

High export growth in Cambodia resulted largely from its relatively early access to the US (in 1996) and
European Union (EU) market on a Generalised System of Preferences (GSP) basis. These markets respectively accounted for almost all garment exports of Cambodia in 2005 (Suiwah et al. 2005), which in turn accounted for half of overall export growth in 2004. ${ }^{3}$

Despite high growth, the Cambodian export base is still extremely narrow, comprising essentially of garment and tourism. Garment export has since 1998 become the single largest export item (36.4 per cent) and occupied a predominant share in total exports of goods and services. The number of agriculture and aquaculture export items is very few, with relatively small shares since 2000 (Suiwah et al. 2005). Together with high trade openness, this narrow export base has resulted in large fluctuations in export turnover.

Notably, among the three economies, Cambodia has faced the highest (two-digit) merchandise trade deficit during the 2000s. But thanks to the net service export surplus (largely contributed by the tourism sector) and official transfer, the CA deficit has been substantially reduced.

Laos has recorded a relatively stable annual growth rate of about 6-7 per cent since 2000; the lowest among the CLV countries. ${ }^{4}$ Despite being the biggest 
Table 2 CLV economic structure by sector, 2000-5 (\%; current price)

\begin{tabular}{lcccccccccc}
\hline & \multicolumn{3}{c}{ Cambodia } & \multicolumn{3}{c}{ Laos } & \multicolumn{3}{c}{ Vietnam } \\
\cline { 2 - 11 } & $\mathbf{2 0 0 0}$ & $\mathbf{2 0 0 3}$ & $\mathbf{2 0 0 5}$ & $\mathbf{2 0 0 0}$ & $\mathbf{2 0 0 3}$ & $\mathbf{2 0 0 5}$ & $\mathbf{2 0 0 0}$ & $\mathbf{2 0 0 3}$ & $\mathbf{2 0 0 5}$ \\
\hline Agriculture, fishery and forestry & 35.9 & 33.2 & 31.4 & 52.1 & 49.1 & 46.0 & 24.6 & 22.5 & 20.7 \\
Industry & 21.8 & 25.8 & 27.0 & 23.5 & 25.7 & 27.9 & 36.7 & 39.5 & 40.8 \\
Services & 37.1 & 36.1 & 36.2 & 24.4 & 25.2 & 26.1 & 38.7 & 38.0 & 38.5
\end{tabular}

Notes Total shares of three sectors of Cambodia do not equal 100\% because in its GDP structure does not include the component 'taxes less subsidies'; Laotian data on 2005 are estimates. Source Cambodian Ministry of Economy and Finance (2006), IMF (2005), CIEM (2006).

sector, agriculture has played a declining role in the country's economic growth; its growth decreased from 8.2 per cent in 1999 to about 2.2 per cent in 2003.

The Laotian merchandise export performance has not been as good as in Cambodia. During 1999-2003, exports and imports have exhibited unclear growth trend; in particular, the growth rate of merchandise export was very low. However, with the opening up and expansion of gold and copper mines since 2003, the surge in mining exports led to an estimated 50 per cent of total export growth in 2005.

Like the case of Cambodia, the Laotian export base is very narrow, mainly comprising wood products, garments and electricity. The export markets are also very limited in number, comprising the EU (garment), Thailand (wood products and electricity) and Japan and the USA (timber and furniture), due to reasons such as landlocked geography, a primitive infrastructure and relatively limited economic integration.

Despite huge trade deficits, Laotian CA deficit has also been much narrowed thanks to foreign exchange earnings from the tourism sector, official transfer, and particularly from private overseas remittances.

Vietnam has achieved quite remarkable economic growth, averaging at 7.5 per cent p.a. during 2001-5. In 2006, the growth rate is estimated at 8.2 per cent. Among CLV, Vietnam is perhaps the most industrialised nation (Table 2). During 2001-5, the industry-construction sector grew most rapidly (10.24 per cent per annum), and made the greatest contribution to growth. Growth rates of services and agriculture-forestry-fisheries sector moderated at nearly 7 per cent and 3.8 per cent per annum (CIEM 2006).

For over two decades, Vietnam's international trade has expanded rapidly in absolute terms and relative to GDP. The ratio of total merchandise trade to GDP increased from about 50 per cent in 1990 to over 133 per cent in 2005. Its trade growth, attaining mostly at two-digit level in recent years, has outpaced those of Cambodia and Laos (Table 1).

Like Cambodia and Laos, Vietnam experienced a rather high trade deficit. But unlike those countries, Vietnam has persistently suffered from a relatively huge deficit in both trade and services (interest payment and FDI profits). Yet Vietnam seems to have no problem with the $C A$, which has even been in surplus in 2005 due to the large amount of private transfers, at US\$3-4 billion (Table 1). Moreover, its export base has been relatively broad both in terms of commodity and market, and has been widened and diversified.

The impressive external performance has been largely due to increasing trade and investment liberalisation and market-oriented reforms, large pools of low-cost labour and natural resources, and sizeable FDI inflows.

Given the rather good macroeconomic performance, a natural question to be asked is: can the CLV sustain economic growth and trade performance? The answer is, in the medium term, the three economies can maintain rather high growth, yet risks of unsustainability remain. 
Table 3 Savings and investment in CLV, 2000-5 (\% of GDP)

\begin{tabular}{lcccccccccc}
\hline & \multicolumn{3}{c}{ Cambodia } & \multicolumn{3}{c}{ Laos } & \multicolumn{3}{c}{ Vietnam } \\
\cline { 2 - 10 } & $\mathbf{2 0 0 0}$ & $\mathbf{2 0 0 3}$ & $\mathbf{2 0 0 5}$ & $\mathbf{2 0 0 0}$ & $\mathbf{2 0 0 3}$ & $\mathbf{2 0 0 5}$ & $\mathbf{2 0 0 0}$ & $\mathbf{2 0 0 3}$ & $\mathbf{2 0 0 5}$ \\
\hline Domestic savings & 17.6 & 16.4 & 17.1 & 16.3 & 20.5 & NA & 27.1 & 27.4 & 30.0 \\
Total investment & 20.6 & 19.4 & 21.4 & 20.4 & NA & NA & 29.6 & 35.4 & 38.9 \\
Source Vo Tri Thanh (2006), Cambodian Ministry of Economy and Finance (2006) and & & & \\
wum.unctad.org/sections/ldc_dir/docs/Idcmisc20053_lao_en.pdf & & & & &
\end{tabular}

For the Cambodian economy, the discovery of offshore oil and natural gas could double the country's economic growth rate, as the oil and gas production projects are planned to start-up in 2009 and 2011 respectively. Apart from positive impacts of UTO accession, non-garment sectors are also expected to develop faster as private sector reform has been accelerated. The agricultural sector promises a further development due to the diversification process and increasing infrastructure investment.

Yet certain risks of unsustainable economic growth persist in Cambodia. First, as previously mentioned, its economic growth relies heavily on garment manufacturing/export and tourism, which are both vulnerable to domestic and external shocks. For example, in the near future, its garment exports to the US and EU markets could significantly slow down as these countries are scheduled to remove safeguard measures against very competitive garment exports from China. The narrow base of economic growth creates a pressing need to nurture new sources with significantly higher rates of productivity and investment.
Nevertheless, increase in public investment is constrained by the very limited government revenue base, while private investment is impeded by an unfavourable business environment (ADB 2005).

Second, from the experience of East Asia, high domestic savings are vital for sustainable economic growth in the long term. The country's gross domestic saving rate has significantly increased, but was still very low and virtually unchanged during 2000-5 (about 17 per cent of GDP). Nonetheless, it was a climb from an average level of 11.1 per cent during 1995-9 (Table 3).

Last, but not least, the sustainability of economic growth depends to a significant extent on the effectiveness and efficiency of macroeconomic management and the above-mentioned restructuring reforms and WTO accession commitment implementation.

Regarding the Laotian economy, it may be difficult to achieve a higher and sustainable growth in the longer term. As mentioned earlier, key impeding

Table 4 Key indicators of CLV's external debts, 2000-5 (\%)

\begin{tabular}{|c|c|c|c|c|c|c|}
\hline & 2000 & 2001 & 2002 & 2003 & 2004 & 2005 \\
\hline \multicolumn{7}{|c|}{ Debt service (\% of export of goods and services) } \\
\hline Cambodia & 8.0 & 3.1 & 2.8 & 2.9 & 2.3 & 1.9 \\
\hline Laos & 5.7 & 7.8 & 8.9 & 6.8 & 9.4 & 16.3 \\
\hline Vietnam & 10.5 & 10.6 & 8.3 & 8.0 & 6.7 & 6.1 \\
\hline \multicolumn{7}{|c|}{ Total external debt/GDP } \\
\hline Cambodia & 65.6 & 62.7 & 64.0 & 64.9 & 58.9 & 51.7 \\
\hline Laos & 83.2 & 82.7 & 88.8 & 104.0 & 90.8 & 112.8 \\
\hline Vietnam & 41.1 & 38.5 & 38.0 & 39.9 & 38.0 & 35.2 \\
\hline
\end{tabular}


Table 5 Budget deficit of CLV, 1999-2005 (\% GDP)

\begin{tabular}{lccccccc}
\hline & $\mathbf{1 9 9 9}$ & $\mathbf{2 0 0 0}$ & $\mathbf{2 0 0 1}$ & $\mathbf{2 0 0 2}$ & $\mathbf{2 0 0 3}$ & $\mathbf{2 0 0 4}$ & $\mathbf{2 0 0 5}$ \\
\hline Cambodia & -3.8 & -4.3 & -6.2 & -7.4 & -5.5 & -3.8 & -2.8 \\
Laos & N/A & -4.4 & -4.0 & -4.0 & -5.8 & -3.9 & N/A \\
Vietnam & -4.4 & -3.4 & -4.9 & -4.1 & -4.7 & -4.0 & -4.7
\end{tabular}

Source Cambodian Ministry of Economy and Finance (2006), IMF (2005), Vo Tri Thanh (2006).

factors include: (a) a small industrial base and heavy dependence on subsistence agriculture; (b) landlocked geography, with a rudimentary infrastructure, and limited external and internal telecommunications; (c) lack of human resources and low domestic savings (20.5 per cent GDP in 2003); (d) persistent macroeconomic instability, particularly double-digit inflation rates over recent years; and (e) heavy trade and economic dependence on the regional countries, ${ }^{5}$ particularly Thailand, which means a higher risk of being affected by contagion from economic slowdown in neighbouring countries.

Despite being more advanced, Vietnam is still challenged in terms of economic growth sustainability due to numerous weaknesses and constraints. Her export structure is still characterised by a large proportion of agriculture and semiprocessed, low value-added merchandises, which are very vulnerable to trade shocks or disputes. The shares of manufacturing and high-tech exports are still relatively small, with the share of the former being equivalent to its East Asian counterparts in the 1980s (about 40 per cent). A significant shift in economic (by sector and ownership) and export structure has taken place, but is still insufficient to ensure sustainable growth.

Furthermore, the country's economic growth has for years been dominated by the SOEs and relied on State investment, ${ }^{6}$ which accounted for more than 50 per cent of total investment but with low efficiency. The SOEs are the very principal debtors of the state-owned commercial banks (SOCBs). With an uncertain level of contingent government liabilities associated with the need to restructure SOEs and SOCBs, debt sustainability could eventually come under threat (IMF 2006c).

It is projected that Vietnam's trade and current account deficits will continue. However, this would lead to no serious outcomes if capital 'productivity' gains outweigh financing costs of the deficits. Thus, it is crucial to ensure a high long-term sustainability of the deficits and external debts.

\section{Capital flow adequacy and external debt burdens}

As the development of the CLV has depended very much on foreign savings, it is important to look at the adequacy of capital flows and external debt of these countries.

Over the period 2001-5, net capital flows to Cambodia were more than necessary to finance the CA deficit. Because FDI and ODA inflows have been major sources of $C A$ deficit financing and securities markets remain non-existent, the risks of sudden capital withdrawing from the country are low.

As at year-end of 2005, total outstanding public debt (of which more than 90 per cent is external debt) accounted for US\$3.2 billion or equivalent to 52 per cent of GDP (Table 4). Nearly two-thirds of the external debt is bilateral debt owed to the Russian Federation and the USA during the period of political strife. They have not been serviced as they are under re-negotiation. ${ }^{7}$

Moreover, almost all of Cambodian external debt has been long-term and appears to be under control due to: (1) that most external debt is on concessional terms, and debt service payments are modest in terms of export; and (2) the debt sustainability indicators appear to be well below the alarming levels.

However, the risk of debt distress may result from low revenue collection of the Cambodian government, which could impede the government against covering public debt and narrowing the country's high budget deficit. This can be observed during 2001-3 (Table 5). 


\begin{tabular}{|c|c|c|c|c|c|c|}
\hline \multicolumn{7}{|c|}{ Table 6 Vietnam's CA balance and its financing sources, 1990-2005 } \\
\hline & \multicolumn{2}{|c|}{$1990-8$} & \multicolumn{2}{|c|}{ 1999-2001 } & \multicolumn{2}{|c|}{$2002-5$} \\
\hline & $\begin{array}{l}\text { Annual } \\
\text { average } \\
\text { (US\$ million) }\end{array}$ & $\begin{array}{l}\% \mathrm{CA} \\
\text { balance }\end{array}$ & $\begin{array}{l}\text { Annual } \\
\text { average } \\
\text { (US\$ million) }\end{array}$ & $\begin{array}{l}\% \mathrm{CA} \\
\text { balance }\end{array}$ & $\begin{array}{l}\text { Annual } \\
\text { average } \\
\text { (US\$ million) }\end{array}$ & $\begin{array}{l}\% \mathrm{CA} \\
\text { balance }\end{array}$ \\
\hline Current account balance & -1048.6 & 100.0 & 869.7 & 100.0 & -977.3 & 100.0 \\
\hline Capital account balance & 1051.2 & - & -295.3 & - & $2,804.3$ & - \\
\hline FDI (net) & 1095.9 & - & 532.0 & 61.2 & 1577.5 & - \\
\hline $\begin{array}{l}\text { Medium- and long-term } \\
\text { borrowings (net) }\end{array}$ & -38.2 & 3.6 & 491.0 & 56.5 & 637.8 & - \\
\hline Short-term borrowings (net) & -6.4 & 0.6 & -919.3 & - & 6.3 & - \\
\hline Portfolio investment & & & & & 750 (2005) & - \\
\hline Deposit & & & -399.0 & - & 395.3 & - \\
\hline Errors and omissions & -168.3 & 16.1 & -266.0 & - & -504.3 & 51.6 \\
\hline Overall balance & -165.7 & 15.8 & 308.3 & 35.5 & 1322.8 & - \\
\hline
\end{tabular}

Notes FDI comprise disbursed equity and external borrowings. Portfolio investment took place in 2005 by issuing US\$750 million of the government bonds in international markets.

Source State Bank of Vietnam (SBV) and authors' calculation (cited from Vo Tri Thanh 2006).

Laos has long been a highly indebted country, and was put under the high risk category among lowincome countries. The ratios of total debt to GDP, exports and government revenues are all rather high. For instance, the ratio of total external debt to GDP jumped from more than 82 per cent in 2000 to nearly 113 per cent in 2005 (Table 4). In principle, Laos is eligible for high indebted poor country (HIPC) debt relief; nevertheless, the authorities have stated that they do not intend to seek HIPC assistance.

Almost all of Laos' external debt is long term, representing a proportion of 98 per cent of total debt during 1995-2002. Furthermore, about 70 per cent of the debt stock at the year-end of 2003 was concessional loans from bilateral and multilateral creditors (primarily the World Bank and the ADB). The biggest bilateral creditor is the Russian Federation, accounting for almost 80 per cent of the stock of bilateral debt at year-end of 2003 (the debt is under negotiation).

The debt projections of the IMF (2004) show that, in the medium-term, the debt service burden is manageable, but only if economic reforms, especially the fiscal ones, are maintained. Revenue collection in Laos has been virtually as low as in Cambodia but much lower than in Vietnam. For example, during 2002-3, Laotian total tax revenue was equivalent to 9.1 per cent of GDP compared with 7.5 per cent in Cambodia during the 2000-2 period and 15.8 per cent in Vietnam for the same period (IMF 2004). Low revenue collection may result from the country's deep-rooted structural weaknesses such as (1) inadequacy in technical capacity of the revenue administration; (2) a highly decentralised revenue administration, in which provinces have weak incentives to collect and remit revenue to the national budget; and (3) proliferation of tax exemptions to stimulate investments, which has further narrowed the revenue base (IMF 2004).

In general, Vietnam's CA deficits during the 1990-8 and $2002-5$ periods were mostly financed by FDI inflows, ${ }^{8}$ accounting for 105 per cent and 161 per cent of the CA balance, respectively (Table 6). ODA, 80 per cent of which being concessional loans, has also been an important medium and long-term financing source since 1999. Commercial loans are 
made predominantly by long-term debt, accounting for 90 per cent during 2000-3.

Since the agreement on debt restructuring with the Russian Federation in 2000, Vietnam's external debt has substantially decreased. In relative terms, total external debt as proportion of GDP went down from 41.1 per cent in 2000 to 35.2 per cent (US\$18.2 billion) in 2005 (Table 5). As a result, Vietnam has escaped from a HIPC status within a short time span.

Vietnam's ratio of total debt to export (51.7 per cent in 2005) and debt service ratio (6.1 per cent in 2005) are all well within a 'controllable' level, and projected to decline in the next 3-4 years. The country's external debt will continue to increase in absolute terms, but her capacity to serve foreign debt is still regarded as relatively high.

There are, however, some concerns about external debt management. The debt-induced finance has constituted a majority of capital inflow in Vietnam and hence, the costs of financing CA deficit may increase. The FDI inflow has also entailed considerable commercial loans. Moreover, the proportion of non-concessional loans has tended to increase and borrowings at floating interest rates become more vulnerable to world interest rate fluctuations. Finally, the capital-using efficacy has been diminishing and therefore, if not properly dealt with, it would adversely affect external sustainability in the forthcoming years.

Some new arising issues should also be properly addressed. First, a surge of portfolio inflow in 2006 into Vietnam's stock market may increase the risks of capital reversal related to the overheating of the stock market, which has been driven by irrational exuberance, sizeable foreign participation and the herding behaviour of investors. Second, during 2002-5, the overall surplus increased significantly. Except for the increasing contribution of FDI and ODA, this was also due to withdrawal of deposits by Vietnamese commercial banks from abroad to provide credit for some 'white elephant' projects and issuing government bonds to the value of US\$750 million in the international market (to make on-lending to the state-owned ship-building corporation VinaShin). Third, the errors and omissions in the BoP are still high due to statistical errors and, to a certain extent, reflect shortcomings in controlling short-term capital flows.

\section{Fragility of financial sector}

After decades of civil strife, Cambodia has made tremendous efforts in reintroducing a banking system, particularly via easing licensing requirements. This resulted in the proliferation of weak joint venture banks, whose problems eventually hampered the return of confidence in the banking system. Efforts to strengthen the banking system were then accelerated and led to closures of 15 banks under a re-licensing programme. Meanwhile, Cambodia also emphasised restructuring the remaining SOCB (the Foreign Trade Bank - FTB) in the direction of privatisation and strengthening commercial decisionmaking. Additionally, accounting standards and banking supervision have recently been strengthened.

The banking reforms have brought about significant fruits. To date, the banking sector has had low levels of non-performing loans (NPLs) in the context of rapid credit expansion. ${ }^{9}$ Indeed, the NPL ratio fell remarkably from 12.4 per cent in 2000 to 7.8 per cent in 2005, although it is still quite high. The capital adequacy ratio (CAR) of Cambodia's banking system has also been significantly improved. As of September 2006, CAR stood at 28.3 per cent, much higher than the regulatory limit of 15 per cent (which used to be 20 per cent until 2005) and well above the 8 per cent Basel Accord requirement.

Despite considerable progress in restructuring, Cambodia's banking system still has numerous weaknesses and constraints.

First, there has been an extremely high degree of 'dollarisation' in the Cambodian economy. As of the end of 2005, 94 per cent of deposits and 93 per cent of lending were made in US dollars. This can also be observed in the microfinance sector, whose credit risk may be higher, as up to 58 per cent of microfinance loans are lent to the agriculture sector.

Second, the banking sector is highly concentrated. The top five banks already account for 71 per cent of total deposits and the top three banks represent 62 per cent of total credit. The concern over loans concentration was addressed by the National Bank of Cambodia (NBC) in November 2006 through amendment of the regulation governing large exposure loans.

Third, credit risk is high due to the fact that banking returns on asset $(R O A)$ is very low (2.4 per cent), yet 
the interest rate is very high (18 per cent per year) despite enormous efforts to restrict interest hikes. This may result from the lack of effective legal framework and difficulties in finding creditworthy customers, which require commercial banks to set high interest rates to compensate for operation costs and interest expenses.

Fourth, Cambodia's banking regulations still do not adequately conform to the Basel Capital Accord. According to an informal assessment by the IMF, several concerns were raised as the 25 Core Principles were not covered by the law and regulations. Another barrier is the development level of the banking system: Cambodia's banking system is very young in terms of the base it stands on (public confidence, regulatory and legal frameworks) and its sophistication (products, information system and human resource). Hence, the NBC set a higher CAR for banks than as set out in the Basel I. Far from full implementation of Basel I, the NBC now focuses on the compliance with the 25 Core Principles, the foundation of effective banking supervision. As for Basel II, Cambodia needs more time.

In conjunction with market-oriented reforms and liberalisation, Vietnam has substantially reorganised its banking sector in the late 1980s and continued to do so to a lesser extent during the 1990s. In early 2000, the banking reforms concentrated on restructuring the four large SOCBs and putting them on a commercial footing. The reforms also aim at establishing and strengthening regulatory, supervisory, and institutional frameworks for more efficient banking and consolidating numerous small and undercapitalised joint stock banks (JSBs). Recent important steps have been, for example, phasing-out of policy lending; phasing-in of prudential standards (e.g. the requirement on CARs); improving accounting and disclosure standards, transparency by adopting International Accounting Standards (IAS) and audits and loan classification (IMF 2004).

Laos has similarly undertaken banking reforms but with less emphasis on banks' internal capacity for change. To date, important measures to avoid further deterioration of banks' balance sheets comprise prohibition of lending to defaulting borrowers, commitment to avoiding new non-commercial lending, setting credit ceilings, and providing incentives for improving banking performance.
It is worth repeating that, unlike Cambodia, Vietnam and Laos made utmost efforts to restructure their SOCB-dominated banking systems and foster nonstate commercial banks' development. In particular, Vietnam has strongly committed to opening its financial sector, including the banking sector, for other WTO members to operate from 2007 onwards.

Despite such progress, numerous problems and concerns remain for the banking sector in both countries. Contrary to the case of Cambodia, in Vietnam and Laos, the SOCBs have been major players in both borrowing and lending markets (70-80 per cent of total market shares) and the most important lenders for SOEs. Apart from directed lending, connected nepotism led to inefficient investment projects and improper supervision which, in turn, has for years resulted in sizable NPLs, particularly by the SOEs. In 2003, Vietnam's NPL ratio to GDP (7.7 per cent) outnumbered those of Laos (3.0 per cent) and Cambodia (1.1 per cent) (Unteroberdoerster 2004). Owing to the country's utmost efforts, its ratio of NPLs to total loans fell sharply to 3.4 per cent in 2005. Nevertheless, under international loan classification, the ratio would be three- or four-fold higher. Similarly, NPL ratios in Laotian SOCBs ranged from over 20 per cent to about 70 per cent, with about 70 per cent of all NPLs considered state related, i.e. lent to SOEs or for policy purposes.

Like Cambodia, Laos has suffered from very high dollarisation. The ratio of foreign currency deposits is extremely high in Laos, accounting for about 80 per cent of its money supply. Despite a lessening influence on Laos' economy after the Asian crisis, the Thai baht is still widely used in Laos. Except for payment for daily necessities and utilities made in the domestic currency of kip, payment is mostly made in baht or US dollars (Hayashi 2003). To a lesser extent, Vietnam has also been facing the problem of dollarisation. Measured as ratio of foreign currency deposits to M2, dollarisation in Vietnam remained stable between 20-23 per cent in the mid-1990s; started to increase in 1997 to reach a peak of 31.7 per cent in 2001; before dropping to 24.4 per cent in 2005 (Vo Tri Thanh 2006).

The maturity mismatch in Vietnam's banking system is also of concern. Despite upward tendency of medium- and long-term deposits, the short-term ones still account for 75 per cent of total deposits. 


\section{Figure 2 Ratios of foreign currency deposits to total deposits and foreign currency loans to total credit in Vietnam, 1996-2005}

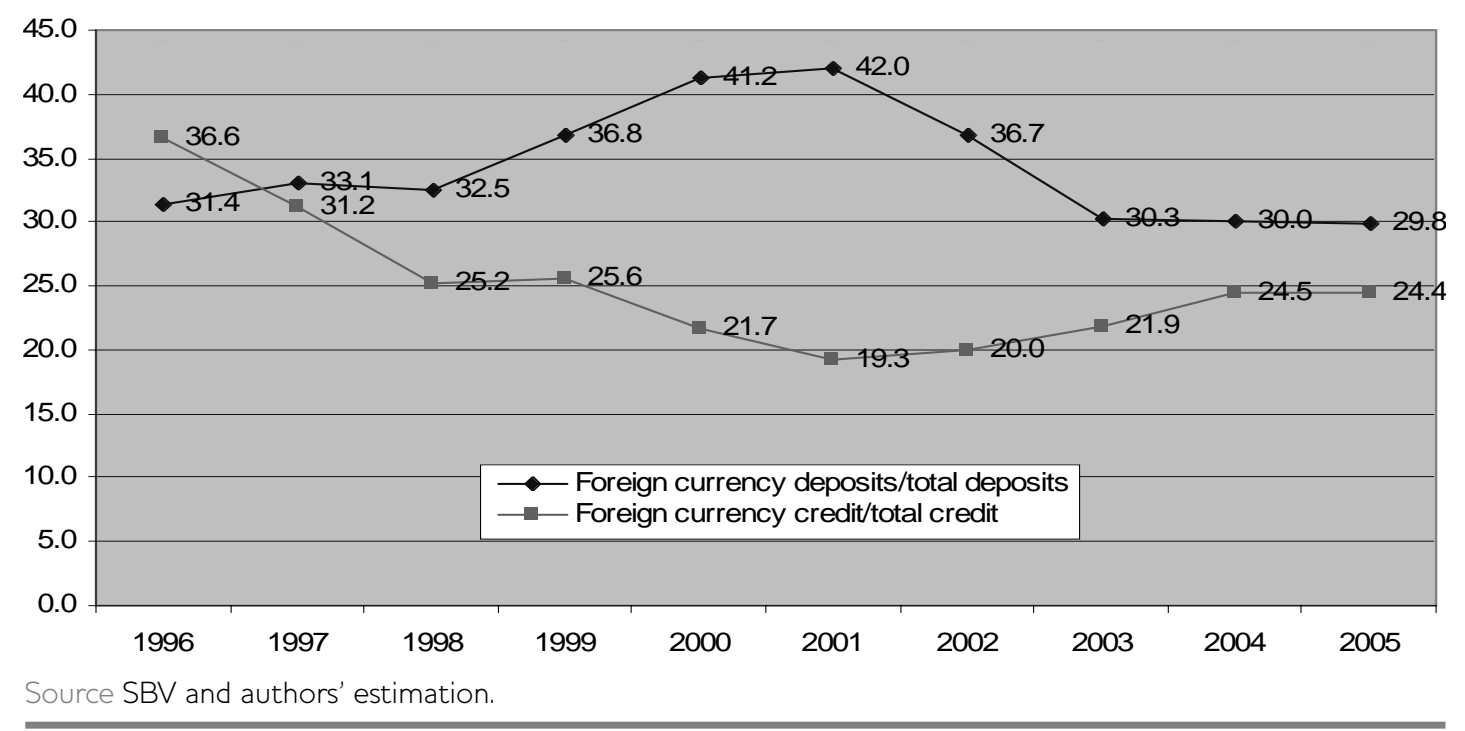

Meanwhile, the commercial banks have been allowed to use about 25-30 per cent of short-term deposits to make medium- and long-term loans. In fact, the share of these loans in total credit increased from 22 per cent in 1995 to about 40 per cent in recent years. The risks may be higher in the presence of directed lending and moral hazard, especially related to loans to the efficacy-questionable big projects.

The currency mismatch was most severe during 1999-2002 due to a sharp increase in foreign currency deposits and a decrease in foreign currency loans, respectively measured as the shares in total deposits and total loans (Figure 2). It has recently been narrowed, but is still problematic due to its sensitivity to exchange rate and interest rate fluctuations, especially in the context of high dollarisation.

The credit structure by sector has changed slightly despite a considerable shift in economic structure. Indeed, the shares of total outstanding loans to agriculture-forestry-fishery and industry sector in 1995 were 26.5 per cent and 37.5 per cent, respectively; in 2005, the corresponding figures were 29.7 per cent and 39.8 per cent (SBV 2006). The highly fragmented banking market caused by commercial banks assigned to lend to particular sectors $^{10}$ has to a certain extent restrained the risksharing of banking system to external shocks and narrowed borrowing choices of businesses.
Of other concern, the SOCBs give priority to asset growth over profitability and capital adequacy, allowing interest rate margins to erode tremendously as they have largely refrained from raising lending rates while offering higher deposit rates to finance rapid credit growth. As a result, capital asset ratios (under domestic accounting standards) declined further, and SOCB restructuring has likely become more costly (Unteroberdoerster 2004).

Vietnam's banking system is still vulnerable due to limited supervision, monitoring and governance capacity. On-site monitoring and supervision is constrained due to inadequate quantity and quality of human resource. Off-site supervision, meanwhile, fails to meet contemporary requirements in compiling and processing information. Lending supervision is yet to cover all credit-related financial institutions due to lack of effective collaboration among authorised agencies and de facto institution-based financial system governance. Certain international practices and standards have recently been adopted; yet banking governance standards are generally yet to meet the CAMEL and Basel provisions.

Vietnam's capital market is still in the early stage of development. The stock market only started operating in 2000, but with enormous growth potential. The equitisation of SOEs, including big general corporations and SOCBs, has significantly 


\section{Box 1 Can a bubble-and-bust happen with the Vietnamese stock market?}

In 2006, Vietnam's stock market skyrocketed in terms of market capitalisation, price, number of listed companies and investors' accounts, participation of securities companies, and investment management funds (see below). Approximately, US $\$ 0.8-1.2$ billion of foreign indirect investment entered Vietnam in the first 10 months of 2006. About 70 per cent of this flow was invested in stocks, bonds and property (30 per cent parked as deposits with the banking system). In December 2006, there were 1,700 accounts of foreign investors owning about 25-30 per cent of listed stocks.

\begin{tabular}{lll}
\hline & $\mathbf{2 0 0 6}$ (year-end) & $\mathbf{2 0 0 5}$ (year-end) \\
\hline Market capitalisation (\% of GDP) & $22.77 \%$ (US\$14 billion) & $1.1 \%$ \\
VN-index (HCMCSTC) & 752 & 305 \\
HASTC-index (HASTC) & 243 & 91.3 \\
Number of listed firms & 193 & 41 \\
HCMCSTC & 106 & 32 \\
HASTC & 87 & 9 \\
Investment funds & 4 & 1 \\
Securities companies & 55 & 14 \\
Management investment funds & 18 & 6 \\
Number of investors' accounts & 100,000 & 30,000
\end{tabular}

Note HCMC STC: Ho Chi Minh City Securities Trading Centre (established in 2000). HN STC: Hanoi Securities Trading Centre (established in 2005).

Key factors behind the market development, inter alia, can be the country's WTO accession and its bright outlook in subsequent years, irrational exuberance and sizeable foreign participation, including the overseas Vietnamese in Russia and Eastern Europe; and herding behaviour spreading among the unsophisticated domestic short-term individual investors in the context of lack of information disclosure and transparency. The number of listed firms increased even more rapidly, perhaps in response to the due expiration of the provided to listed companies' incentive in the form of corporate income tax deduction. It is worth noting that the total value of OTC stock market is estimated to be three-six times higher than that of the formal market.

In response, Vietnam's State Securities Commission (SSC) has repeatedly warned investors of risks associated with the overheating market development and, simultaneously, undertaken measures to mitigate risks and prevent market collapse. The first measure undertaken in December 2006 was to restrain the size of stocks-collateralised loans and loans to bank-backed securities companies, and other (financial institution-backed and 'independent') securities companies. A few days later, the SSC promulgated six measures to improve regulation and monitoring of securities market's operations. First, as the Prime Minister decided to postpone the lifting of maximum shares of listed companies permitted to foreign investors, the SSC would try to inform the market of this information as quickly as possible. Second, the SSC would cooperate with the State Bank of Vietnam (SBV) to monitor lending for security investment, repo transactions and other transactions related to security collateralisation of commercial banks. Third, the SSC also acts to investigate the securities companies which are reported to discriminate between customers, and/or misuse information. Fourth, the SSC shall require the listed companies to disclose and disseminate their operational and financial results in 2006, to better inform investors in the market. Fifth, re-registration would be implemented for representative offices of foreign investment funds in Vietnam. Sixth, the SSC strives to promote further information disclosure, so that the investors can make rational investment decisions.

Source Authors' compilation and estimation from various sources. 
increased opportunities for investors, whereas barriers to foreign investment continue to be relaxed. The bond market is still very small. In 2006, total outstanding bonds were equivalent to 10 per cent of GDP and only 3 per cent of total outstanding debt was of corporate bonds. Moreover, nearly all Government bonds are on primary issues, while secondary trading has been quite rare.

In Vietnam, the last few years have seen two new problems which stem largely from the real-estateand stock-collateralised loans. The former are related to the frozen real estate market, while the latter are to the booming stock market. Notably, both the frozen real estate market and booming stock market have many hidden risks, particularly a bubble-and-bust one which can eventually create huge NPLs for banks, or even cause a collapse of the financial market if managed improperly. Several recent measures by Vietnam's government for improving regulations and monitoring the stock market have obviously revealed its concern about the market development (Box 1). An important issue for the government is how to deter perceived 'speculative' interest in Vietnam, while retaining investment needed for the development of Vietnam's economy (ANZ 2007).

The current conditions of the real estate market and stock market may also erode the development of the country's infant bond market, arguably important for reducing both currency and maturity mismatches in the financial market. It can be said that, in 2006, the very active stock transactions have totally crouded out bond transactions. Unlike previous years, in 2006, there were no bond transactions in formal securities market and the urban bonds were much less liquid.

\section{Exchange rate regime and international}

\section{reserves}

Cambodia and Laos have adopted a dual exchange rate regime since 2002 (Fan 2004) after a prolonged period of high inflation. The official exchange rate, applying to external transactions by the government and state enterprises, is adjusted daily to maintain a spread of less than 1 per cent and 1.5 per cent in Cambodia and Laos, respectively, against the market rate which applies for all other transactions (UNESCAP 2005).

In 1989, Vietnam officially abandoned and unified its multiple exchange rates. Since then, the exchange rates for transactions have been set within an adjusting band around the official rate announced by the SBV. The band was gradually widened from 0.5 per cent in 1991 to 10 per cent in October 1997 in response to the Asian crisis. Since February 1999, the SBV began announcing the average inter-bank exchange rate of the previous working day, but the band for transactions has been tightened remarkably to 0.1 per cent. The band was widened to 0.5 per cent in December 2006.

All three countries have seemingly attempted to use the nominal exchange rate 'anchor' to restrain inflation. During 2002-5, the Cambodian riel depreciated by 2.11 per cent on average (NBC 2006), while the Laotian kip depreciated by less than 4 per cent during 2002-4. During 2004-6, the Vietnamese dong depreciated by about 1 per cent per annum against the US\$. Moreover, as the CLV have all suffered from high dollarisation, which can be seen as mobile short-run capital flows 'within-theeconomy', the effectiveness of monetary policy can be undermined to a significant extent.

All three countries, therefore, have paid careful attention to the exchange rate policy. Cambodia has adopted a managed floating exchange rate regime and the objective of its exchange rate policy is confined to price stability rather than supporting export industry. Since the exchange rate stands largely under political and psychological factors, it is important for the monetary authority to step into the local foreign exchange markets. The US dollar auction has been used carefully, but not to deal with depreciation arising from fundamental imbalance or to resist global pressure (Beresford et al. 2004). The exchange rate regime in Laos is also regarded as 'managed floating'.

The exchange rate arrangement of Vietnam is classified as a 'pegged regime within horizontal bands'. The country is currently concerned about the continued upward pressure on local currency due to a surge in capital inflows. Using sterilisation to keep local currency from appreciation while avoiding inflationary pressure could be very costly. Another concern is how to develop an effective hedging mechanism for exchange rate transactions. To date, the derivative instruments such as forward, option and swap have been adopted in the country's foreign exchange market, but are still at an infant stage of development. 


\begin{tabular}{|c|c|c|c|c|c|c|}
\hline \multicolumn{7}{|l|}{ Table 7 CLV's foreign reserves, $2000-5$} \\
\hline & 2000 & 2001 & 2002 & 2003 & 2004 & 2005 \\
\hline \multicolumn{7}{|l|}{ Cambodia } \\
\hline Gross foreign reserves (US\$ million) & 502 & 587 & 776 & 816 & 943 & 952 \\
\hline Gross foreign reserves (months of imports) & 2.7 & 2.8 & 3.1 & 3.1 & 2.7 & 2.5 \\
\hline \multicolumn{7}{|l|}{ Laos } \\
\hline Gross foreign reserves (US\$ million) & 141 & 133 & 196 & 216 & 225 & NA \\
\hline Gross foreign reserves (months of imports) & 2.6 & 2.6 & 3.5 & 3.2 & 3.0 & NA \\
\hline \multicolumn{7}{|l|}{ Vietnam } \\
\hline Gross foreign reserves (US\$ million) & 3,417 & 3,675 & 4,121 & 6,224 & 7,041 & 8,369 \\
\hline Gross foreign reserves (months of imports) & 2.6 & 2.7 & 2.5 & 3.0 & 2.6 & 2.7 \\
\hline
\end{tabular}

Though derivatives may pose some macroeconomic risks, they do help protect companies and banks from risks. Therefore, a careful assessment may be required of the desirable pace and modalities for development of the derivatives markets.

A positive observation is that gross foreign reserves have risen in all three countries. Yet in relative terms, they have tended to decline in recent years. Judging by the IMF optimal criteria (IMF 1998), they also appear to be low and far from being optimal (six months of imports of goods and services) (Table 7). Furthermore, the size of foreign reserves seems to be insufficient, considering the vital role of foreign reserves in protecting the economy from policy/external shocks, especially those linked to the capital account. In these cases, dollarisation further complicates the problem, since it could be similar to the foreign exchange liquidity problem in having too much short-term external debt; panic could happen if it is perceived that the supply of foreign currencies may not be forthcoming.

The adequacy of the level of foreign exchange reserves should also be examined in relation to the health of the financial system and the appropriateness of the exchange rate regime.

\section{Conclusions and policy recommendations}

After two decades of market-oriented reforms and international economic integration, the CLV countries have recorded impressive achievements, notably high economic growth. Current prospects for a financial crisis appear to be relatively low for CLV as fertile grounds for its eruption, such as overborrowing syndrome, severe currency and maturity mismatch, long-lasting fixed exchange rate, etc. have not co-existed.

Despite the possibility of sustaining high growth in the medium term, vulnerabilities of economic growth and financial systems still remain in the CLV. Important reasons for such concern are that, to a different extent, these economies (1) still rely significantly on external resources to finance the investment-savings gap in economic development; meanwhile, domestic capability to serve and absorb efficiently those resources is limited; (2) can be hit by international trade shocks and disputes, and a global recession; and (3) have been financially nurtured by ailing banking systems caused largely by a legacy of previous distorted macroeconomic management schemes; (4) have very large levels of dollarisation (especially Cambodia and Laos), which - as is known from international experiences - can imply greater vulnerability to shocks.

While failing to meet international standards and best practices, each individual financial system has its own peculiar weaknesses and constraints. Cambodia's banking system has long been disadvantaged by an insufficiently developed regulatory framework, weak intermediaries and low public confidence. Those of Laos and Vietnam, meanwhile, have suffered heavily from NPLs and other consequences left by a centrally planning mechanism. Vietnam's stock market is still in the 
early stage of development, but risks have already emerged, given its meteoric rise. Also, Vietnam currently lacks several fundamental conditions for sound development of the bond market, especially the corporate bond market.

Therefore, this article suggests the following common and country-specific policies to sustain CLV economic growth and to foster sustainable financial systems in the context of deepening economic integration.

First, sustainable economic growth in the CLV countries requires further market-oriented reforms and the strengthening of macroeconomic fundamentals. The WTO and/or other international commitment-driven institutional adjustments can play a crucial role in this process. The countries need to improve their business environment to attract both domestic private investment and FDI. ODA should be utilised more efficiently and transparently, which depends on both coordination among donors and capacity building for the host countries. Due attention should also be paid to diversifying exports and improving the quality of human resource.

Laos and Vietnam should be more serious about tackling public investment inefficiency. For Cambodia and Laos, significantly increasing domestic savings will provide a crucial additional pool for local private sector development. This depends not only on income growth but also on people's confidence in the banking system.

Second, as the securities markets of the three countries are either non-existent or only at an early stage of development, having a sound banking system is vital. There are pressing needs to improve regulatory framework, to strengthen banking supervision, to improve risk management, to apply widely international auditing and accounting standards, to recapitalise commercial banks, and to enhance human resource capacity.

Regarding Cambodia, it is crucial to promote financial intermediation, especially lending activities. Accordingly, the country needs to: (a) strengthen the Credit Information Sharing (CIS) system, promote the use of international standards, practices of accounting standards and corporate financial statements; (b) strengthen contract enforcement; and (c) enhance the availability and quality of financial services in rural areas.
Meanwhile, Laos and Vietnam should go towards creating a competitive level playing field for banking of all forms. It is vital to strengthen creditor rights by providing banks with more effective means to resolve NPLs, especially to loss-making SOEs. Connected lending should also be prevented. In general, outcomes of banking reforms largely depend on progress in SOE reform and enforcement of hard budget constraints.

To resolve the NPL problem, Vietnam's SOCBs need a stronger mandate. The delay in equitisation of the VietcomBank and Mekong Housing Bank is problematic The recent establishment of the Vietnam Development Bank (2006) and the decision to equitise four SOCBs in 2007 - including VietcomBank, IncomBank, Bank for Investment and Development and the Mekong Housing Bank - are expected to help mitigate the NPL problem and strengthen their soundness in the coming years. Moreover, the projects financed by Government investment bonds through on-lending should be subject to rigorous screening and supervision. Effective enforcement of the new anti-corruption laws to curb corruption and prevent the waste of public funds would be an integral part of this endeavour.

Third, having a more balanced financial system should be a long-term objective of the CLV. This contributes not only to enhancing efficient resource allocation and to mitigating financial risks, but also to an effective engagement of the CLV in regional financial integration.

Cambodia and Laos should give priority to establish government bond markets. To mobilise additional capital for development and to strengthen corporate governance, it is important for both countries in the long term to have their joint-stock companies listed in stock exchanges. Due to their relatively small size, it is perhaps more rational to encourage their businesses to go floating abroad rather than establishing their own stock exchanges. Another option would be to develop regional stock markets.

For Vietnam, the key is to lay down all fundamental conditions for sound development of her capital market. This requires establishment and/or strengthening of financial institutions, secondary government bond market, financial regulations, credit rating companies, judicial systems, accounting and disclosure standards, and clearing and settlement arrangements. Currently, it is also important for 
Vietnam to properly regulate stock market-related credit (with the need to study establishing some limits on credit levels for this purpose), to discourage insider trading, and to enhance information disclosure and transparency and professionalism of individual investors. Together with growing scope for securities market operations after the WTO accession, three securities-related regulators - namely, the SSC and the Ministry of Finance and the SBV - need to adopt a unified framework to detect vulnerabilities associated with portfolio capital movements.

Fourth, experience has shown that financial crises can follow an inappropriate sequencing of financial and capital account liberalisation. Therefore, the CLV should have a proper roadmap or sequencing for financial integration and liberalisation. In a widely adopted roadmap, trade liberalisation should first be introduced and coupled with structural reforms; followed by internal financial liberalisation and finally, external financial liberalisation to ensure a safe, proper process of multi-stage liberalisation.

In principle, a good choice of exchange rate regime needs to be consistent with the sustainable international competitiveness of the exchange rate and to have room for exchange rate fluctuations to provide some space for domestic monetary policy. In practice, the economies with rather closed CA can pursue an adjustable peg exchange rate scheme. ADBI and APF (2000: 12) emphasised that these economies 'should give high priority to building a strong banking system and sound long-term, domestic-currency denominated securities markets'; they 'should also strive for strong macroeconomic fundamentals', such as low inflation, and high domestic saving and investment rates. These recommendations seem to be relevant to the case of Vietnam.

At present, Cambodia and Laos seem to be quite comfortable with their exchange rate regimes. Yet the choice of dual exchange rate regime remains questionable. Dual exchange rate regime may be acceptable in dealing with small size foreign exchange market and pervasive information asymmetry in the market. However, the benefits of foreign exchange unification, at least to avoid misallocation of resources, have been recognised by the central banks in their long term objectives. Yet as pointed out by Fan (2004), in bringing down inflation and improving external balance while implementing exchange rate unification, suitable fiscal and monetary policies must be adopted to support these goals. In addition, it is unclear how Cambodia and Laos can continue with such an extremely high degree of dollarisation in the long term. Indeed, an important policy objective may be to significantly reduce the degree of dollarisation of those economies.

Fifth, the CLV countries lack information and accurate and consistent statistics, particularly financial and BOP statistics. Moreover, these statistics do not conform well to international standards, despite considerable improvements with respect to their collection, processing and dissemination. Obviously, their quality should be improved and only based on that, the Early Warning System for detecting vulnerability of financial system, which is of great importance in the coming years, can be developed and used with high credibility. 


\section{Notes}

* The opinions expressed in this article are solely those of the authors and do not necessarily reflect those of the affiliated institutions, the Central Institute for Economic Management of Vietnam (CIEM) and the National Bank of Cambodia (NBC).

1 The reforms were sponsored by the International Monetary Fund and included an overhaul of the tax system, a two tier-banking system, tariff reduction and privatisation.

2 In 2000, Vietnam and the USA signed the Bilateral Trade Agreement, which became effective in December 2001. Since then, Vietnam has also joined several regional integration clubs such as ASEAN + 1 Free Trade Areas. Most importantly, Vietnam became the 150th member of the UTO in November 2006.

3 Note that the re-imposition of restrictions by the USA and EU on clothing imports from China in the second half of 2005 was a key factor contributing to the increase in Cambodian garment exports.

4 Unless otherwise indicated, data in this subsection is adapted from or calculated based on the IMF (2005).

\section{References}

ADB (2005) Asian Development Outlook 2005:

Promoting Competition for Long-term Development, Hong Kong: Asian Development Bank

ADBI and APF (2000) Policy Recommendations for

Preventing Another Capital Account Crisis, Tokyo: ADBI

ANZ International Economics Monthly (February 2007)

'Vietnam: Rising Risk of Capital Controls'

Beresford, Melanie; Nguon, Sokha; Roy, Rathin; Sau, Sisovanna and Namazie Ceema (2004) The Macroeconomics of Poverty Reduction in Cambodia, Phnom Penh: United Nations Development Program (UNDP)

Cambodia Ministry of Planning (2006) National Account of Cambodia 1993-2005, Phnom Penh: Ministry of Planning, Royal Government of Cambodia

Cambodian Ministry of Economy and Finance (2006) 'Cambodia Economic Report 2006', paper prepared for the Informal ASEAN+3 Finance and Central Bank Deputies Meeting (AFDM+3), Siem Reap, Cambodia

Central Institute for Economic Management (CIEM) (2006) Vietnam's Economy 2005, Hanoi: Political Theory Publishing House
5 During 2001-4, the averaged share of intra-GMS (Greater Mekong Subregion) trade to total trade of Laos was highest (63 per cent) among six GMS countries (Cambodia, China, Laos, Myanmar, Thailand and Vietnam).

6 In Vietnam, the 'state investment' consists of investment outlays from budget, state credit (mostly associated with ODA) and investment attained from SOE profits.

7 See: www.adb.org/Documents/Reports/TMRforeign-direct-investment/chap-2.pdf

8 In 2004-5, the capital account attained US\$2,753 million and US\$3,179 million, respectively. FDI capital flow accounted for the biggest part of the total capital inflow to Vietnam, amounting to US\$1,610 million in 2004 and US\$1,850 million in the same period.

9 During 2002-August 2006, total credit to the economy rose 26.4 per cent annually on average, channelled primarily towards manufacturing, retail and wholesale sectors, and personal consumption.

10 For instance, the Bank for Agriculture and Rural Development is assigned primarily to provide credits to agricultural and rural sector.

Fan, Emma Xiaoqin (2004) A Note on Dual/Multiple Exchange Rates, ERD Policy Brief 26: May, Manila, Philippines: Asian Development Bank

Hayashi, Tomoko (2003) Experiences and Lessons of Monetary and Financial Systems in East Asia, Economic and Social Research Institute, March, www.esri.go.jp/en/tie/ea/ea5-le.pdf

ICSEAD (2006) 'Recent Trends and Prospects for Major Asian Economies', East Asian Economic Perspectives 17, February, Kitakyushu: The International Centre for the Study of East Asian Development

IMF (2006a) Cambodia: 2006 Article IV Consultation, IMF Country Report 06/264d, Washington DC: International Monetary Fund

IMF (2006b) International Financial Statistics June 2006, Washington DC: International Monetary Fund

IMF (2006c) Vietnam: Selected Issues, IMF Country Report 06/20, January

IMF (2005) Lao People's Democratic Republic: Selected Issues and Statistical Appendix, IMF Country Report 05/9, January

IMF (2004) Vietnam: Selected Issues, IMF Country Report 03/381: September 
IMF (1998) Financial Programming and Policies, Workshop Reading Materials, Hanoi: IMF NBC (2006) NBC Annual Report 2006, Phnom Penh: National Bank of Cambodia

State Bank of Vietnam (2006) Annual Report 2006 Hanoi: SBV

Suiwah, Leung; Vo Tri Thanh and Kem Reat Viseth (2005) Integration and Transition - Vietnam, Cambodia and Lao PDR, Working Papers 05-1, Asia Pacific School of Economics and Government, Australian National University UNESCAP (2005) Economic and Social Survey of Asia and the Pacific 2005: Dealing with Shocks, New York: UNESCAP
Unteroberdoerster, Olaf (2004) Banking Reform in the Lower Mekong Countries, IMF Policy Discussion Paper 04/5: September, Asia and Pacific Department

Vo Tri Thanh (principal researcher) (2006) A Strategy of Mobilizing and Utilizing Capital for Industrialization and Modernization in Vietnam, Project KX-02-08 of the State Research Program KX-02 'Industrialization and Modernization in Vietnam: Roadmap and Paces', Hanoi, October (in Vietnamese) 